\title{
Towards a comprehensive picture of lakes: biogeochemistry, biodiversity, production and food web relationships revisited
}

\author{
M. Alvarez-Cobelas ${ }^{1, *}$, C. Rojo ${ }^{2}$ and S. Sánchez-Carrillo ${ }^{1}$ \\ ${ }^{1}$ Museo Nacional de Ciencias Naturales (CSIC), Serrano 115 dpdo., 28006 Madrid, Spain. \\ 2 Instituto Cavanilles de Biodiversidad y Biología Evolutiva, Universidad de Valencia, Apartat Oficial 2085, \\ 46071 Valencia, Spain. \\ * Corresponding author: malvarez@mncn.csic.es
}

Received: 24/10/18 Accepted: 26/09/19

\begin{abstract}
Towards a comprehensive picture of lakes: biogeochemistry, biodiversity, production and food web relationships revisited

Theoretical Limnology is a neglected topic nowadays. Here we make an endeavour to launch and promote theoretical developments in Limnology, dealing with the mechanistic relationships among biogeochemistry, production, species richness and food webs in the most common-sized lakes, i.e. small-to-medium ones. Although few studies are currently underway to support includes such relationships, well-known interactions enable us to place such lakes within a conceptual model bottom-up model, which include water retention, total phosphorus and dissolved organic carbon as the driving variables. All response variables are viewed on the basis of area, which enables circumventing the otherwise important issue of depth (and hence stratification). Seven lake types are considered with unique sets of features concerning species richness, food web connectance, nutrient fluxes and lake metabolism.

The extension and tuning of this conceptual model to all stagnant waters (from small to large) can be undertaken when more data on these topics are available, probably taking horizontal transport features into account. We look forward to seeing future developments in theoretical Limnology, also paying special attention to Mediterranean limnological features which differ somewhat from those of cold temperate- and tropical areas.
\end{abstract}

Key words: Theoretical limnology, mechanistic processes, phosphorus, dissolved organic carbon, water renewal, food-web connectance, bacterial and lake production, lake respiration, nutrient export

\section{RESUMEN}

Hacia una imagen unitaria de los lagos: revisando las relaciones entre biogeoquímica, biodiversidad, redes tróficas y producción

La Limnología teórica es un tema olvidado en estos tiempos. Por eso, aqui proponemos un intento modesto de iniciar y promover teorías limnológicas, explorando las relaciones mecanicistas entre biogeoquímica, producción, riqueza específica y redes tróficas para los tipos más frecuentes de tamaño de lago, que son los pequeños y medianos. Aunque el número de estudios que ofrece resultados para apoyar dichas relaciones es bastante reducido, algunas bien conocidas de estas facilitan el organizar los lagos dentro de un esquema conceptual que usa la retención del agua, el fósforo total y el carbono orgánico disuelto como variables de control. Considerar todas las variables de respuesta por unidad de superficie permitirá pasar por alto el importante asunto de la profundidad, y el de la estratificación térmica por lo tanto. Nuestro esquema conceptual vislumbra siete tipos de lagos con conjuntos de respuestas únicas relativas a la riqueza de especies, la conectancia de las redes tróficas, los flujos biogeoquimicos y la productividad lacustre.

Una mayor concreción de este modelo conceptual y la extensión del mismo a todos los ambientes estancados (de los pequeños a los grandes) podrán llevarse a cabo cuando haya más datos sobre estos temas, probablemente teniendo en cuenta además alguna variable relativa al transporte horizontal. Tras esta contribución, nos gustaría ver nuevos desarrollos teóricos que-además-presten atención a la Limnología mediterránea, la cual difiere un poco de la existente 
en las zonas templadas frías y tropicales del globo.

Palabras clave: Limnología teórica, procesos mecanicistas, fósforo, carbono orgánico disuelto, renovación del agua, conectancia de redes tróficas, exportación de nutrientes

Contemplo o lago mudo que uma brisa estremece. Não sei se penso em tudo ou se tudo me esquece 1 .

Fernando Pessoa

\section{INTRODUCTION}

It is beyond any reasonable doubt that Ecology is a synthetic science, and so it follows that Limnology -as a part of Ecology- is too. Works by Thoreau (1854; see Alvarez Cobelas, 2017) and Forbes (1887) delved into the topic providing earlier insights, Forbes being far more influential and well-known that the former. Subsequently, Limnology has undergone further development, which can be traced through books by Forel (1901), Ruttner (1940), Hutchinson (1957-1993), Dussart (1966), Margalef (1983), Lampert \& Sommer (1993), Kalff (2001), Wetzel (2001), Dodds \& Whiles (2010) and Tundisi \& Matsumura-Tundisi (2012), among others. All in all, synthesis is implied by those books in their description of Limnology. However, despite certain writings (Rigler \& Peters, 1995), the current state of Limnology is that of a purely descriptive science where synthesis is also descriptive, if not overlooked or lost in a plethora of novel discoveries of single, albeit fascinating, details. Attempts made to scale-up Limnology to a planetary scale science are valuable (see Downing, 2009), but they miss the fact that any given science must be predictive to be truly useful. Furthermore, prediction must rely on a solid theoretical basis. Concerning physics, for example, the first great advance occurred when XVII century research by Kepler, Galileo and Newton (among others) gave rise to better theories that were useful to predict planetary movements.
However, to date such theories cannot be applied to Limnology, as a part of Ecology, because the wealth of very different organisms precludes a simple treatment of relationships among them and the environment.

Scientists strive daily to increase and expand knowledge, but much remains to be done. We have managed to predict ecological dynamics, but the great wealth of data on ecological structure and function available nowadays hinders more in-depth prediction. Paraphrasing Shakespeare: "we cannot see the lake for the algae"; in other words, lake algae prevent us from envisaging lake functioning.

Let us now look at what can be called "theoretical limnology", which is certainly an elusive concept. The word "theoretical" has shone in the title of Societas Internationalis Limnologiae since at least 1922 (Elster, 1974). No limnological textbook defines what theoretical limnology actually is, nor do influential books devoted to theoretical ecology (May \& McLean, 2007). However, we would like to venture a definition for "theoretical limnology", namely general limnological knowledge independent of its application. Implicitly, we assume that theoretical limnology is the abstract knowledge of inland waters, one which emerges from searching for commonality (i.e. generality; Wetzel, 2001) in limnosystems.

It is shocking to find that on entering the topic "theoretical Limnology" in a literature search within the Web of Science platform (WOS,

${ }^{1}$ I contemplate the lake / which is ruffled by the breeze / I know not if I think about anything / or if I forget everything. 
Thomson Reuters) for the 1990-2018 period, just 36 references appear, most of which do not encompass any theory whatsoever, but rather the want of it. The lack of references found using those keywords prompted us to search for other concepts, such as "theoretical aquatic sciences", "theoretical freshwater sciences", "theoretical lake ecology" and "theoretical river ecology", but again few results were found (between 49 and 184 references). Of course, searching for limnological details is more rewarding, but it takes more than building bricks alone to build a palace.

By contrast, a search for "theoretical Ecology" on the same platform and for the same period renders more than 5000 citations. So why is Limnology so poor concerning novel theoretical developments? To answer this question would take us far beyond the scope of this journal, but we could certainly find some roots and explanations related to the sociology of limnologists (mostly elderly natural historians) and to funding (mostly given to applied topics, the European Water Directive included). Jumars (1990) warned against this fact long ago in the USA, but such warnings still apply in the European scientific arena. Considering oceanography, a close scientific discipline, oceanographers are forced to dive into theory more than limnologists are, because ocean science would otherwise be unapproachable. Inland waters appear to be "accessible", which results in limited approaches and failure to expand knowledge. Nonetheless, it is also true to say, and worthy of mentioning, that some developments in theoretical ecology have arisen from limnological studies (Talling, 2011), such as those on plankton stoichiometry (Elser \& Hassett, 1994) and alternative stable states (Scheffer, 1997).

Furthermore, current limnology relies deeply on statistical relationships among bulk environmental properties (e.g. "phosphorus", "biomass"); a fact that probably has its roots in the influential Vollenweider studies (1968, 1975). The most common approach to limnology nowadays is to infer processes from the empirical patterns they produce, which is called "the inverse problem" and is typically difficult to solve because many processes might produce similar patterns (Wood, 1997). In addition, statistics frequently neglects mechanisms in the aquat- ic realm (Kiørboe, 2008) and gives rise to different, often conflicting, interpretations. Concerning freshwater science, the interesting assay by Downes (2010) suggests that i) models fit data poorly, thereby lowering confidence in inference, and ii) there is a strong need to specify precise mechanisms of cause and effect. Such efforts, currently neglected, would certainly promote theoretical limnology and maybe foster Ecology as a predictive science.

We therefore believe the time has come to start a new Limnology, deeply rooted in mechanistic science, which will provide future researchers with theoretical foundations, thus enabling prediction and the building of a framework for novel, detailed discoveries. This article is a humble endeavour in that direction.

\section{AN ATTEMPT TO DIVE INTO STAGNANT THEORETICAL LIMNOLOGY}

Curiosity drives us to suggest a novel lentic Limnology where structure and function could be related in a mechanistic way, and not only statistically, as is the rule nowadays. An approach that might contribute to such an endeavour, albeit incipient as compared with biodiversity or food webs, is biogeochemistry. In fact, very preliminary studies suggest that there could be a relationship between food webs and biogeochemical fluxes in lakes because 1) the removal of the top predator would increase $\mathrm{CO}_{2}$ outgassing (Schindler et al., 1997) and 2) $\mathrm{CO}_{2}$ emission from the lake appears to be inversely related with species richness (Morin \& McGrady-Steed, 2004).

Primary production is also related with biogeochemical fluxes, e.g. the higher the primary production, the lower the $\mathrm{CO}_{2}$ emission from the lake because higher oxygen production offsets lake respiration (Duarte \& Prairie, 2005), and the lower nutrient (N, P) export from the lake as well (Harris, 1999). Likewise, there happens to be a relationship between food webs and productivity since they become longer as production increases (Sabo et al., 2009; Takimoto \& Post, 2013), although ecosystem size (and hence ecosystem heterogeneity) should also be taken into account (e.g. Havens et al., 1996). On the other hand, biodiversity and productivity relationships exist, 
Table 1. Some predicted links between biodiversity, food-webs, productivity and biogeochemistry in small-to-medium temperate lakes related to nutrient content and water retention. All variables must be viewed on an areal basis. These predictions were gathered from literature references (see main text) and have been compiled by the authors of this chapter. [ ]: substance concentration; biodiversity: species richness; C: carbon; DOC: dissolved organic carbon; Export: downstream export; F: flux; N: nitrogen; P: phosphorus; bact PN: non-photosynthetic net bacterial production; bent PN: net benthic production; plankt PN: net planktonic production; Resp: whole community respiration; $\mathrm{T}_{\mathrm{W}}$ : water retention time. Arrows in fluxes indicate high ( $\left.\uparrow\right)$, very high ( $\uparrow$ ) or low flux ( $\downarrow$ ). Algunas predicciones de las vinculaciones entre biodiversidad, red trófica, producción y flujos biogeoquímicos en distintas situaciones nutritivas y de tiempo de retención de los lagos templados de tamaño moderado. Todas las variables deben considerarse por unidad de área. Se basa en distintos trabajos de distintos autores (citados en el texto) que han permitido a los autores de este capitulo confeccionarla. [ ]: concentración de sustancias; Biodiversidad: riqueza especifica; C: carbono; DOC: carbono orgánico disuelto; Export: exportación aguas abajo por vía fluvial; F: flujo; $N$ : nitrógeno; $P$ : fósforo; $P N$ bact: producción neta bacteriana (no fotosintética); PN bent: producción neta bentónica; PN plankt: producción neta planctónica; Resp: respiración de toda la comunidad; $T_{W}$ : tiempo de residen-

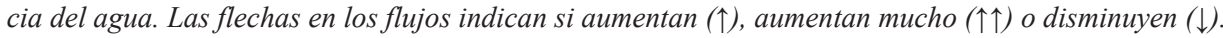

1) Negligible groundwater- and/or stream inputs; high $T_{w}$

A) Nutrients: [low DOC] [low P]

Biodiversity as species richness: medium Food web: Low or medium connectance

Production: bent PN >>plankt PN; low bact PN; low or medium Resp Biogeochemistry: $\mathrm{F}\left(\mathrm{CO}_{2}\right) \uparrow ; \mathrm{F}\left(\mathrm{CH}_{4}\right) \downarrow ; \mathrm{F}(\mathrm{C}-\mathrm{N}-\mathrm{P}$ export $) \downarrow$

B) Nutrients: [high DOC] [low P]

Biodiversity as species richness: low

Food web: Medium connectance

Production: bent $\mathrm{PN} \geq$ plankt $\mathrm{PN}$; high bact $\mathrm{PN}$; medium Resp

Biogeochemistry: $\mathrm{F}\left(\mathrm{CO}_{2}\right) \uparrow \uparrow ; \mathrm{F}\left(\mathrm{CH}_{4}\right) \downarrow ; \mathrm{F}(\mathrm{N}-\mathrm{P}$ export $) \downarrow ; \mathrm{F}(\mathrm{DOC}$ export $) \uparrow$

C) Nutrients: [low DOC] [medium P]

Biodiversity as species richness: high

Food web: high connectance

Production: bent $\mathrm{PN} \approx$ plankt $\mathrm{PN}$; medium bact $\mathrm{PN}$; medium Resp

Biogeochemistry: $\mathrm{F}\left(\mathrm{CO}_{2}\right) \downarrow ; \mathrm{F}\left(\mathrm{CH}_{4}\right) \uparrow ; \mathrm{F}(\mathrm{C}-\mathrm{N}-\mathrm{P}$ export $) \downarrow$

D) Nutrients: [low DOC] [high P]

Biodiversity as species richness: low

Food web: low connectance

Production: bent $\mathrm{PN}<$ plankt PN; high bact PN; high Resp

Biogeochemistry: $\mathrm{F}\left(\mathrm{CO}_{2}\right) \downarrow ; \mathrm{F}\left(\mathrm{CH}_{4}\right) \uparrow ; \mathrm{F}(\mathrm{C}-\mathrm{N}-\mathrm{P}$ export $) \downarrow$

2) Significant groundwater- and/or stream inputs; low $T_{w}$

A) Nutrients: [low DOC] [low or medium P]

Biodiversity as species richness: low or medium

Food web: low or medium connectance

Production: bent PN >> plankt PN; low bact PN; medium Resp

Biogeochemistry: $\mathrm{F}\left(\mathrm{CO}_{2}\right) \uparrow \uparrow ; \mathrm{F}\left(\mathrm{CH}_{4}\right) \downarrow ; \mathrm{F}(\mathrm{C}-\mathrm{N}-\mathrm{P}$ export $) \uparrow \uparrow$

B) Nutrients: [high DOC] [low or medium P]

Biodiversity as species richness: low

Food web: low connectance

Production: bent PN > plankt PN; medium bact PN; medium Resp

Biogeochemistry: $\mathrm{F}\left(\mathrm{CO}_{2}\right) \uparrow \uparrow ; \mathrm{F}\left(\mathrm{CH}_{4}\right) \downarrow ; \mathrm{F}(\mathrm{C}-\mathrm{N}-\mathrm{P}$ export $) \uparrow \uparrow$

C) Nutrients: [low or medium DOC] [medium or high P]

Biodiversity as species richness: medium or high

Food web: medium or high connectance

Production: bent $\mathrm{PN}<$ plankt PN; medium bact PB; medium Resp

Biogeochemistry: $\mathrm{F}\left(\mathrm{CO}_{2}\right)$ ??; $\mathrm{F}\left(\mathrm{CH}_{4}\right) \uparrow ; \mathrm{F}(\mathrm{C}-\mathrm{N}-\mathrm{P}$ export $) \uparrow$ 
but it is still unclear which variable controls which (Cardinale et al., 2009). In fact, Tilman et al. (2001) suggest that more production would result in higher species richness, meaning that the former behaved as a heterogeneous resource for the latter because ecological niches would be more occupied over time due to complementarity; thus the time vector would be important for that relationship. Also, there appears to be some relationship between biodiversity and food webs because a straightforward relationship takes place between species richness and food web connectance (Vermaat et al., 2009).

Last but not least, despite the complexity of all those pairwise interactions, a simple and generalist relationship between biodiversity, food-web, productivity and biogeochemical fluxes could be considered, i.e. as species richness increases, the efficiency of nutrient use by biological communities would be higher due to i) their complementarity using resources, and ii) the higher number of trophic relationships exploiting the trophic space to maintain efficient energy transfer and stability. As a result, nutrient export fluxes will diminish.

Therefore, an approach which encompasses four important features of structure and function in stagnant limnosystems would attempt to link structure, function and nutrient fluxes (Fig. 1). Such an approach then relies upon the following features, some of which still require unequivocal proof: 1) production is related to species richness although it is still unclear which one is controlling the other, 2) species richness is related to food web features through connectance, 3) species richness could have negative effects on biogeochemical fluxes, 4) production shows negative effects on biogeochemical fluxes outside the environment where it occurs, 5) production poses positive effects on food web length, and 6) the absence of top predators in food webs usually results in greater emission of greenhouse gasses from aquatic environments (Fig. 1).

Clearly, mechanistic explanations for all these relationships are few at present, and once again only consider the incipient state of current Ecology as a predictive science. Only the $4^{\text {th }}$ and the $5^{\text {th }}$ relationships mentioned above are suggested to result from ecological mechanisms. While the former arises from the fact that in situ production limits nutrient export because higher production needs more nutrients to be fuelled, high production also enhances food web length because more energy would then be available and this would promote more complex food webs.

It is true to say that in recent years there has been a trend to suggest generalizations, approaches and even theories on partial ecosystem functioning. The best known is the metabolic theory (Brown et al., 2004), which relates temperature and organismic size to predict individual metabolism, from which ecosystem metabolism could be derived by integrative methods. Another novel development relates nutrient import from nearby environments (so-called "subsidies") with food webs (Marcarelli et al., 2009) and nutrient stoichiometry with microbial genetics of the communities involved (Hall et al., 2011). Hence, our effort to relate biodiversity, food web structure, production and biogeochemistry relies on generalizations in an attempt to suggest a more predictable and abstract limnology, which is no longer a mere set of case studies, as currently occurs in most ecological studies on whole limnosystems.

\section{HOW DOES A SMALL-TO-MEDIUM LAKE WORK? A CONCEPTUAL MODEL}

We will restrict our suggestions to small-to-medium lakes because they are the most common all over the world (Downing et al., 2006). Reservoirs will be considered as ecosystems where horizontal transport prevails over vertical transport, and hence they should be included within the larger lake types, falling outside the scope of this work. The main elements defining the model are the following: water residence, dissolved organic carbon (DOC) and total phosphorus (TP) as the main nutrients controlling bacterial and algal production in lakes (Harris, 1999; Dodds \& Cole, 2007), production (benthic and planktonic), respiration (whole lake) and nutrient fluxes to and from the lake (Table 1). Regarding nutrients, if there is plenty of phosphorus we may expect high primary productivity as is the case in eutrophic and hypertrophic environments. Likewise, the same is true for bacterial production when there is plenty of DOC, as long as other factors are not strongly limiting. To overcome the complexity of depth, all 
following explanations and suggestions must take concentrations and processes on an areal basis, i.e. they are for the whole water column. This also circumvents the vertical inhomogeneities arising from stratification when it exists.

As for biodiversity, species richness is the single variable to be considered due to its ease of computation. We assume for the conceptual model that its response to total phosphorus is unimodal (Jeppesen et al., 2000), and hence peak richness takes place at intermediate phosphorus concentrations, a fact also known as Connell's hypothesis (1978). This enables us to suggest that diversity would be medium in a lake with low phosphorus concentrations, as is the case in oligotrophic environments, whereas higher (but not very high) phosphorus concentrations would imply higher species richness, which would also decline as phosphorus increases again (Table 1).

The relationship between species richness and food web links is strong, simply because when species richness is higher, the potential number of links among species increases (Vermaat et al., 2009). This might result in higher connectance (i.e. the proportion of possible links between species that actually occur, usually measured as $\mathrm{L} / \mathrm{S} 2$, where $\mathrm{L}$ is the number of links and $\mathrm{S}$ is the number of species; Dunne et al., 2002), but this relationship -albeit suggested by Dunne et al. (2002) - has not been proven as yet. If such a relationship was true, intermediate levels of nutrients would promote higher species richness, which would imply higher connectance in the food web. On the other hand, there is also another feature that must be explored regarding biogeochemistry and species richness, because different fractions of herbivores and detritivores in freshwaters also affect nutrient flux via uptake and recycling (Vermaat et al., 2009), but this is also a task for the future.

Last but not least, the relationship between primary production and species richness is far from being satisfactorily solved, but Fraser et al. (2015) have proved that it occurs in grasslands worldwide as a humped-back relationship (Grime, 1973). However, it is still unclear which variable controls which and the underlying mechanisms involved are still unclear (Fraser et al., 2015).

Biogeochemical fluxes and productivity relationships appear to be less straightforward, because they depend not only upon the substance concerned but also upon the geological lake basin and the geographical location as well. Regarding $\mathrm{CO}_{2}$, the initial studies (Cole \& Caraco, 1998) stated that low productivity lakes emitted more carbon dioxide than more productive lakes and hence they were usually net heterotrophic (Duarte $\&$ Prairie, 2005). However, it was later demonstrated that ecosystem respiration was not always the main cause for $\mathrm{CO}_{2}$ outgassing; rather, carbon dioxide emissions were mostly due to surface or subterranean geological inputs, and they derived from transformations of the carbonic-carbonate system, which could be mediated by organisms (photosynthesis) and/or geochemical processes (Stets et al., 2009). Water renewal is very important for these relationships in small lakes: for example, if such renewal is strong due to high water inputs, retention time will be low and hence productivity would be lower than that in environments where water retention is higher. This is because longer retention times provide more time for ecological processes to develop (Harris, 1999).

If we take methane and the byproducts of denitrification (i.e. $\mathrm{N}_{2}$ and $\mathrm{N}_{2} \mathrm{O}$ ) into account, the relationship between outgassing of gasses and productivity is more straightforward. Higher lake productivity results in more particulate organic matter which promotes more methane production and denitrification in subjacent habitats in two ways: 1) it supplies more substrates to be oxidized, and 2) it generates anoxic layers resulting from bacterial decomposition processes. As a result, methane and nitrogen emissions to the atmosphere increase (Piña-Ochoa \& Alvarez Cobelas, 2007, Ortiz-Llorente \& Alvarez Cobelas, 2012). The fluxes of other elements, such as those of phosphorus, usually depend upon their input concentration, but also upon water renewal (Harris, 1999).

Notice that all these hypotheses and suggested lake responses belong to the bottom-up type. The cause is that food web control by predators (i.e. the top-down approach) enables fewer options to link all processes and structures considered here (biodiversity, production, food webs and biogeochemical fluxes). Furthermore, the role of top predators in this context has scarcely been dealt with (but see Schindler et al., 1997; Marotta et 
al., 2012; Sánchez-Carrillo et al., 2018). In addition, remarkably, top-down approaches are more useful in purely planktonic food webs; however, small-to-medium lakes usually harbour very important littoral and benthic food webs, which are often subsidized by plankton, and where little is known about the trophic behaviour of predators (e.g. benthic fish). Despite the multitude of studies on food preferences and behaviour of benthic fish (e.g. García-Berthou 1994, 2001), the number of studies dealing with their importance in food webs and biogeochemistry is still scarce in climates other than the cold temperate one. It is still hard to know how fish control food-web features and/or nutrient fluxes and transformations. To our knowledge, only Sánchez-Hernández et al. (2015) have reported data on food web connectance in Spanish mountain lakes while Rubio-Gracia et al. (2017) have dealt with cyprinids and biogeochemistry in streams and, recently, Sánchez-Carrillo et al. (2018) have studied the effect of the abiotic environment on the food web structure of a small lake in central Spain. Therefore, a great deal of knowledge is still needed. In fact, it has been suggested that trophic cascades behave more often than not as "trickles" rather than as "cascades" in small-to-medium, Mediterranean lakes (Alvarez Cobelas et al., 2005a).

So far we have talked about medium- or small lakes. Otherwise, further variables related to lake size would have to be included, most of which have scarcely been explored to date in the way suggested here. Some of these variables are the following: the heterogeneity and extent of littoral communities; the quantity of inputs of subterranean and/or surficial discharge as compared with the whole lacustrine volume (i.e. water renewal), and horizontal transport. Water stratification would be a negligible process in our conceptual model because all variables involved could be estimated on an areal basis.

All previous assumptions lead us to suggest small-to-medium lakes behave differently, taking dissolved organic carbon, total phosphorus and water renewal into account (Table 1). Such behaviours embrace species richness, production, food webs and biogeochemisty (see Fig. 1) using both proven- and some presumed relationships



Figure 1. Relationships among biodiversity (as species richness), food web, production and biogeochemical flux in a small-to-medium sized lake. Concerning biogeochemical flux, $\mathrm{C}$ fluxes are the main ones represented here. Arrow direction indicates control of one process by the other, but it is still debatable in some cases (two arrows in a given line). Relaciones entre la biodiversidad, la red trófica, la producción y los flujos biogeoquímicos en un lago de tamaño pequeño o mediano. En el caso de los flujos biogeoquímicos, están representados principalmente los del carbono. El sentido de las flechas implica algún tipo de control; cuando son dobles, aún no se ha concluido qué aspecto controla al otro.

among them. Therefore to give an example of hypothetical predictions of lake functioning (Table 1), in a high water retention lake with low concentrations of DOC and TP (hence an oligotrophic and uncoloured lake) (case 1.A), there will be medium species richness and, consequently, there might be medium food web connectance. Since it is oligotrophic and poorly coloured, this enables the establishment of submerged macrophytic communities, whose primary production would exceed that of plankton. The low DOC content in such a lake would not promote high bacterial production. Overall respiration of the whole lake would be low or medium, but higher than primary production, and this would result in significant outgassing of $\mathrm{CO}_{2}$ to the atmosphere. However, methane and nitrogen emissions from the lake would be low because there would be few hotspots for their producing bacteria to live due to both oxic conditions and methane oxidation (Segers, 1998). The low water renewal would make nutrient export low downstream.

The remaining outcomes and interrelation- 
ships between biogeochemistry, biodiversity, production and food webs are easily derived from our assumptions as above (Table 1). So in a lake with high water renewal, high DOC and low-to-medium $\mathrm{P}$ content (case 2.B), species richness would be low, the food web would show low connectance, benthic net production would be higher than planktonic net production whereas bacterial production would also be intermediate as occurs with overall respiration, and finally $\mathrm{CO}_{2}$ outgassing and $\mathrm{C}-\mathrm{N}-\mathrm{P}$ downstream export would be high, but $\mathrm{CH}_{4}$ outgassing would be low (Table 1). For some types of environment, such as lakes with high phosphorus content and high water renewal (case 2.C), it is hard to know how important $\mathrm{CO}_{2}$ outgassing would be. The review that Hanson et al. (2015) devote to lake organic carbon does not talk about hypertrophic lakes with short water retention times (see their Fig. 2). Obviously, these predictions must await further field data.

\section{THE IBERIAN CASE}

Few attempts have been made in this territory to compile knowledge useful for sketching a global picture of lake functioning. The first overall study on Spanish reservoirs in the seventies (Margalef et al., 1976) provided ample information, but it was still too early to shape them into the novel ideas that would subsequently emerge in the following century. Later, compilations of data on many lake features (species richness, food webs, biogeochemistry) are rare. In fact, there is a dearth of studies on lake food webs in the Iberian Peninsula, except those by Sánchez-Hernández et al. (2015) on mountain lakes, Alvarez Cobelas \& Rojo (2013) on some lowland shallow lakes in Central Spain and Sánchez-Carrillo et al. (2018) on Ruidera lakes. Several, often applied, studies have resulted in wide datasets encompassing many features of Spanish lakes and wetlands (Alvarez Cobelas et al., 2006b, 2015; Camacho et al., 2016; Casamayor et al., 2012; Guillén, 2015; Sánchez-Carrillo \& Angeler, 2010; Sánchez-Carrillo \& Alvarez Cobelas, 2018; Villar-Argaiz et al., 2018) which enable researchers to study all these features jointly to produce an overall, albeit simplified, idea of lake functioning. In Portugal, the situation appears to be worse, because to our knowledge such data simply do not exist, which is due to the fact that most Portuguese limnologists are devoted to stream research.

Therefore, the situation in the Iberian Peninsula is largely unknown and more complex than in cold temperate lakes, where most studies have been undertaken in the last two centuries. Ours are different environments because 1) we lack large lakes (most are shallow and small), but have some huge reservoirs, 2) we have longer vegetative periods, which are also increasing because of climate change (Alvarez Cobelas et al., 2005b), 3) our fish fauna mostly feeds at the sediment interface, and are thus less important for pelagic food webs than in cold temperate lakes.

In order to study all these facts within a wider context we envisage Mediterranean Limnology, which has scarcely received any attention to date (but see Alvarez Cobelas et al., 2005c, and Gasith \& Resh, 1999), as a separate regional topic. Accordingly we would have Mediterranean limnology, cold temperate limnology (Wetzel, 2001) and tropical limnology (Roldán-Pérez \& Ramírez-Restrepo, 2008).

\section{A BRIEF DISCUSSION AND A PLEA FOR THE FUTURE}

The main reason for the currently poor state of theoretical limnology is the prevalence of short-range projects, hindering cooperation among researchers of disparate limnologically related fields (for example, hydrogeology, biogeochemistry, taxonomy and food-web ecology). It would seem that the synthetic nature of limnology, once praised by Thienemann, Hutchinson, Margalef and other saints of our mausoleum, has been forgotten as a result of the urgency to publish and remain in race in the pursuit of funding. An attempt to link microbial and ecosystem ecology through biogeochemistry has been made (Hall et al., 2011), and Jonsson et al. (2005) have proved relationships among food webs, organismic size and abundance. However, it is time to encourage the search for mechanistic relationships among different features of the aquatic environment. Failure to do so will be like adding bricks to a building which lacks a design. The 
usefulness of our limnological science will hence be dubious, and the predictive power of its knowledge remains poor.

All said, from our viewpoint, the current state of theoretical limnology is discouraging. One of the most recent treatises (Dodds \& Whiles, 2010) intends to sketch differences among ecosystem types on the grounds of irradiance, depth and water renewal gradients (see their Fig. 24.14). It is a valuable contribution but fails to give any mechanistic ideas as to how elements and processes are linked in any limnosystem.

Here we intend to encourage thought and promote the concept of theoretical Limnology, paying special attention to the features that Iberian limnosystems do not share with cold temperate and tropical environments. We look forward seeing more studies like this one in the near future. The Iberian Peninsula is a good place to start this task because there are still many Iberian limnologists and because it is a vulnerable area in terms of global change, albeit much less known than both tropical and cold temperate inland waters.

\section{ACKNOWLEDGEMENTS}

This article has benefited from numerous commentaries, criticisms and suggestions by two anonymous referees, and we are very grateful to both. Fabiola Barraclough has checked English language.

\section{REFERENCES}

ALVAREZ COBELAS, M., J. GARCÍA-AVILÉS \& E. ORTEGA-MAYAGOITIA. 2005a. El plancton de las lagunas de gravera y el fósforo: el enriquecimiento de las paradojas. Limnetica, 24: 67-82.

ALVAREZ COBELAS, M., J. CATALÁN \& D. GARCÍA DE JALÓN. 2005b. Impactos sobre los ecosistemas acuáticos continentales. In: Evaluación de los impactos en España por efecto del cambio climático (J.M. Moreno, ed.), 113-146. Oficina Española del Cambio Climático y Universidad de Castilla-La Mancha. Madrid.

ALVAREZ COBELAS, M., C. ROJO \& D. G. ANGELER. 2005c. Mediterranean limnolo- gy: status, gaps and the future. Journal of Limnology, 64: 13-39.

ALVAREZ COBELAS, M., S. CIRUJANO, C. ROJO, M. A. RODRIGO, E. PIÑA, J. C. RODRÍGUEZ MURILLO \& E. MONTERO. 2006a. Effects of changing rainfall on the limnology of a Mediterranean, flowthrough-seepage chain of lakes. International Review of Hydrobiology, 91: 466-482.

ALVAREZ COBELAS, M., S. CIRUJANO, E. MONTERO, C. ROJO, M. A. RODRIGO, E. PIÑA, J. C. RODRÍGUEZ MURILLO, O. SORIANO, M. ABOAL, J. P. MARÍN \& R. ARAUJO. 2006b. Ecología acuática y sociedad de las lagunas de Ruidera. CSIC. Madrid. 414 pp.

ALVAREZ COBELAS, M. \& J. FERNÁNDEZ LÓPEZ (eds). 2013. Limnología básica de algunos humedales de Castilla. LimnoIberia $\mathrm{n}^{\mathrm{o}}$ 1. Grupo de Investigación del Agua. Madrid. 239 pp.

ALVAREZ COBELAS, M. \& C. ROJO. 2013. Síntesis. In: Limnología básica de algunos humedales de Castilla (M. ALVAREZ COBELAS \& J. FERNÁNDEZ LÓPEZ, eds), 169-199. Limnolberia $n^{\circ} 1$. Grupo de Investigación del Agua. Madrid.

ALVAREZ COBELAS, M. \& S. SÁNCHEZ CARRILLO. 2016. Short nutrient fluxes of a groundwater-fed, flow-through lake. Limnetica, 35: 143-158.

ALVAREZ COBELAS, M. 2017. Henry David Thoreau, ¿otro fundador de la Limnología? Alquibla, 56: 15-21.

ATWOOD, T. B., E. HAMMILL, H. S. GREIG, P. KRATINA, J. B. SHURIN, D. S. SRISTAVA \& J. S. RICHARDSON. 2013. Predator-induced reduction of freshwater carbon dioxide emissions. Nature Geoscience, 6: 191-194. DOI: 10.1038/NGEO1734

BROWN, J. H., J. F. GILLOOLY, A. P. ALLEN, V. M. SAVAGE \& G. B. WEST. 2004. Toward a metabolic theory of ecology. Ecology, 85: 1771-1789. DOI: 10.1890/03-9000

CAMACHO, A., N. MURUETA, E. BLASCO, A. C. SANTAMAYANS \& A. PICAZO. 2016. Hydrology-driven macrophyte dynamics determines the ecological functioning of a model Mediterranean temporary lake. 
Hydrobiologia, 774: 93-107. DOI: 10.1007/ s10750-015-2590-9

CARDINALE, B. J., H. HILlEBRAND, W. S. HARPOLE, K. GROSS \& R. PTACNIK. 2009. Separating the influence of resource availability from resource imbalance on productivity-diversity relationships. Ecology Letters, 12: 475-487. DOI: 10.1111/j.14610248.2009.01317.x

CASAMAYOR, E. O., M. LLIROS, A. PICAZO, A. BARBERAN, C. M. BORREGO \& A. CAMACHO. 2012. Contribution of deep dark fixation processes to overall $\mathrm{CO}_{2}$ incorporation and large vertical changes of microbial populations in stratified karstic lakes. Aquatic Sciences, 74: 61-75. DOI: 10.1007/s00027011-0196-5

COLE, J. J. \& N. F. CARACO. 1998. Atmospheric exchange of carbon dioxide in a low-wind oligotrophic lake measured by the addition of SF6. Limnology and Oceanography, 43: 647-656.

CONNELL, J. H. 1978. Diversity in tropical rain forest and coral reefs. Science, 199: 1302-1310.

DODDS, W. \& J. J. COLE. 2007. Expanding the concept of trophic state in aquatic ecosystems: it is not the autotrophs. Aquatic Sciences, 69: 427-439.

DODDS, W. K. \& M. R. WHILES. 2010. Freshwater Ecology. 2nd edition. Academic Press and Elsevier. Boston and Amsterdam. 841 pp.

DOWNES, B. J. 2010. Back to the future: little-used tools and principles of scientific inference can help disentangle effects of multiple stressors on freshwater ecosystems. Freshwater Biology, 55 (Supplement 1): 60-79. DOI: j.1365-2427.2009.02377.x

DOWNING, J. A., Y. T. PRAIRIE, J. J. COLE, C. M. DUARTE, L. J. TRANVIK, R. G. STRIEGL, W. H. McDOWELL, P. KORTELAINEN, N. F. CARACO, J. M. MELACK \& J. J. MIDDELBURG. 2006. The global abundance and size distribution of lakes, ponds, and impoundments. Limnology and Oceanography, 51: 2388-2397. DOI: 10.4319/lo.2006. 51.5.2388

DOWNING, J. A. 2009. Global limnology: up-scaling aquatic services and processes to the planet Earth. Verhandlungen der Internationale Vereinigung für Limnologie, 30: 1149-1166.

DUARTE, C. M. \& Y. T. PRAIRIE. 2005. Prevalence of heterotrophy and atmospheric $\mathrm{CO}_{2}$ emissions from aquatic ecosystems. Ecosystems, 8: 862-870. DOI: 10.1007/s10021-0050177-4

DUNNE, J. A., R. J. WILLIAMS \& N. D. MARTINEZ. 2002. Network structure and biodiversity loss in food webs: robustness increases with connectance. Ecology Letters, 5: 558-567.

DUSSART, B. 1966. Limnologie: l'Etude des Eaux Continentales. Gauthier-Villars. Paris. $677 \mathrm{pp}$.

ELSER, J. J. \& R. P. HASSETT. 1994. A stoichiometric analysis of the zooplankton-phytoplankton interaction in marine and freshwater ecosystems. Nature, 370: 211-213.

ELSTER, H. J. 1974. History of Limnology. Mitteilungen der Internationale Vereinigung für Limnologie, 20: 7-30.

FORBES, S. A. 1887. The lake as a microcosm. Bulletin of the Scientific Association (Peoria, Illinois), 77-87.

FOREL, F. A. 1901. Handbuch der Seenkunde. Allgemeine Limnologie. J. Engelhorn. Stuttgart. $268 \mathrm{pp}$.

FRASER, L. H. et al. 2015. Worldwide evidence of a unimodal relationship between productivity and plant species richness. Science, 349: 302-305. DOI: 10.1126/science.aab3916

GARCÍA-BERTHOU, E. 1994. Ecologia alimentària de la comunitat de peixos de l'Estany de Banyoles. Tesis Doctoral. Univ. Girona. Girona. 286 pp.

GARCÍA-BERTHOU, E. 2001. Size- and depth-dependent variation in habitat and diet of the common carp (Cyprinus carpio). Aquatic Sciences, 63: 466-476. DOI: 10.1007/s00027-001-8045-6

GASITH, A. \& V. H. RESH. 1999. Streams in Mediterranean climate regions: abiotic influences and biotic responses to predictable seasonal events. Annual Review of Ecology and Systematics, 30: 51-81.

GRIME, J. P. 1973. Control of species density in herbaceous vegetation Journal of Environ- 
mental Management, 1: 151-167.

GUILLÉN, A. 2015. Lago de Sanabria: presente y futuro de un ecosistema en desequilibrio. Edición del autor. Zamora. 245 pp.

HALL, E. K., F. MAIXNER, O. FRANKLIN, H. DAIMS, A. RICHTER \& T. BATTIN. 2011. Linking microbial and ecosystem ecology using ecological stoichiometry: a synthesis of conceptual and empirical approaches. Ecosystems, 14: 261-273. DOI: 10.1007/s10021-0109408-4

HANSSON, P. C., M. L. PACE, S. R. CARPENTER, J. J. COLE \& E. H. STANLEY. 2015. Integrating landscape carbon cycling: research needs for resolving organic carbon budgets of lakes. Ecosystems, 18: 363-375. DOI: 10.1007/s10021-014-9826-9

HARRIS, G. P. 1999. Comparison of the biogeochemistry of lakes and estuaries: ecosystem processes, functional groups, hysteresis effects and interactions between macro- and microbiology. Marine and Freshwater Research, 50: 791-811.

HAVENS, K. E., L. A. BULL, G. L. WARREN, T. L. CRISMAN, E. J. PHLIPS \& J. P. SMITH. 1996. Food web structure in a subtropical lake ecosystem. Oikos, 75: 20-32. DOI: $10.2307 / 3546317$

HUTCHINSON, G. E. 1957-1993. A Treatise on Limnology. Vols. 1-4. John Wiley and Sons. New York. 1015, 1115, 660 and 968 pp.

JEPPESEN, E., J. P. JENSEN, M. SØNDERGAARD, T. LAURIDSEN \& F. LANDKILDEHUS. 2000. Trophic structure, species richness and biodiversity in Danish lakes: changes along a phosphorus gradient. Freshwater Biology, 45: 201-218.

JONSSON, T., J. E. COHEN, J. E. \& S. R. CARPENTER. 2005. Food webs, body size, and species abundance in ecological community description. Advances in Ecological Research, 36: 1-84.

JUMARS, P. 1990. W(h)ither limnology. Limnology and Oceanography, 35: 1216-1218.

KALFF, J. 2002. Limnology. Inland water ecosystems. Prentice-Hall. Upper Saddle River, NJ. 592 pp.

KIØRBOE, T. 2008. A mechanistic approach to plankton ecology. Princeton University Press.
Princeton and Oxford. 209 pp.

LAMPERT, W. \& U. SOMMER. 1993. Limnoökologie. Georg Thieme Verlag. Stuttgart. 440 pp.

MARCARELLI, A. M., C. V. BAXTER, M. M. MINEAU \& R. T. HALL jr. 2009. Quantity and quality: unifying food web and ecosystem perspectives on the role of resource subsidies in freshwaters. Ecology, 92: 1215-1225. DOI: 10.1890/10-2240.1

MARGALEF, R., M. D. PLANAS, J. ARMENGOL, A. VIDAL, N. PRAT, A. GUISET, J. TOJA \& M. ESTRADA. 1976. Limnología de los embalses españoles. MOPU. Madrid. 422 pp. + anexos.

MARGALEF, R. 1983. Limnología. Ediciones Omega. Barcelona. 1010 pp.

MAROTTA, H., C. M. DUARTE, B. A. GUIMARÃES-SOUZA \& A. ENRICH-PRAST. 2012. Synergistic control of $\mathrm{CO}_{2}$ emissions by fish and nutrients in a humic tropical lake. Oecologia, 168: 839-847. DOI: 10.1007/ s00442-011-2131-9

MAY, R. M. \& A. R. McLEAN. 2007. Theoretical Ecology. Principles and Applications. 3rd edition. Oxford University Press. 257 pp.

MORIN, P. J. \& J. McGREEDY-STEED. 2004. Biodiversity and ecosystem functioning in aquatic microbial systems: a new analysis of temporal variation and species richness predictability relations. Oikos, 104: 458-466.

MÜLLER, R. A., M. N. FUTTER, S. SOBEK, J. NISELL, K. BISHOP \& G. A. WEYHENMEYER. 2013. Water renewal along the aquatic continuum offsets cumulative retention by lakes: implications for the character of organic carbon in boreal lakes. Aquatic Sciences, 75: 535-545. DOI: 10.1007/s00027-013-0298-3

NEUBERT, M., S. C. BLUMENSHINE, D. E. DUPLISEA, T. JOSSON \& B. RASHLEIGH. 2000. Body size, food web structure, and the cascade model's equiprobability assumption. Oecologia, 123: 241-251.

ORTIZ-LLORENTE, M. J. \& M. ALVAREZ-COBELAS. 2012. Comparison of biogenic methane emissions from unmanaged estuaries, lakes, oceans, rivers and wetlands. Atmospheric Environment, 59: 328-337. DOI: 10.1016/j.atmosenv.2012.05.031 
PIÑA-OCHOA, E. \& M. ALVAREZ-COBELAS. 2006. Denitrification in aquatic environments: a cross-system analysis. Biogeochemistry, 81: 111-130. DOI: 10.1007/s10533-006-9033-7

RIGLER, F. H. \& R. H. PETERS. 1995. Science and Limnology. Ecology Institute. Oldendorf/ Luhe. $266 \mathrm{pp}$.

ROLDÁN-PÉREZ, G. \& J. J. RAMÍREZ-RESTREPO. 2008. Fundamentos de Limnología tropical. $2^{\mathrm{a}}$ edición. Editorial Universidad de Antioquía. Antioquía, Colombia. 442 pp.

RUBIO-GRACIA, F., D. ALMEIDA, B. BONET, F. CASALS, C. ESPINOSA, A. S. FLECKER, E. GARCÍA-BERTHOU, E. MARTÍ, B. A. TUULALKHUU, A. VELA-GISPERT, L. ZAMORA \& H. GUASCH. 2017. Combined effects of hydrologic alteration and cyprinid fish in mediating biogeochemical processes in a Mediterranean stream. Science of the Total Environment, 601: 1217-1225. DOI: 10.1016/ j.scitotenv.2017.05.287

RUTTNER, F. 1940. Grundriss der Limnologie. De Gruyter. Berlin. 242 pp.

SABO, J. L., J. C. FINLAY \& D. M. POST. 2009. Food chains in freshwaters. Annals of the New York Academy of Sciences, 1162: 187-220. DOI: $10.1111 / \mathrm{j} .1749-6632.2009 .04445 . x$

SÁNCHEZ-CARRILLO, S. \& D. G. ANGELER (eds). 2010. Ecology of threatened semiarid wetlands. Springer. Dordrecht. 292 pp.

SÁNCHEZ-CARRILLO, S. \& M. ALVAREZ-COBELAS (eds.) 2018. Limnología de la laguna de Somolinos. Síntesis del conocimiento científico. LimnoIberia $\mathrm{n}^{\circ} 12$. CSIC. Madrid. 354 pp.

SÁNCHEZ-CARRILLO, S., D. G. ANGELER, M. ÁLVAREZ-COBELAS \& C. ROJO. 2018. Abiotic drivers of consumer foodweb structure in lakes. Freshwater Science, 37: 404-416. DOI: $10.1086 / 697927$

SÁNCHEZ-HERNÁNDEZ, J., F. COBO \& P. E. AMUNDSEN. 2015. Food-web topology in high mountain lakes. PLOS ONE, 10(11): e0143016. DOI: 10.1371/journal.pone.0143016.

SCHEFFER, M. 1997. Ecology of shallow lakes. Kluwer Academic Publishers. Dordrecht. $356 \mathrm{pp}$.

SCHINDLER, D. E., S. R. CARPENTER, J. J. COLE, J. F. KITCHELL \& M. L. PACE.
1997. Influence of food web structure on carbon exchange between lakes and the atmosphere. Science, 277: 248-251.

SEGERS, R. 1998. Methane production and methane consumption: a review of processes underlying wetland methane fluxes. Biogeochemistry, 41: 23-51.

STETS, E. G., R. G. STRIEGL, G. R. AIKEN, D. O. ROSENBERRY \& T. C. WINTER. 2009. Hydrologic support of carbon dioxide flux revealed by whole-lake carbon budgets. Journal of Geophysical Research, Vol. 114, G01008. DOI: 10-1029/2008JG000783

TAKIMOTO, E. \& D. M. POST. 2013. Environmental determinants of food-chain length: a meta-analysis. Ecological Research, 28: 675-681. DOI: 10.1007/s11284-012-0943-7

TALLING, J. F. 2012. Limnology: definition and objective. In: Limnology (J.G. TUNDISI \& T. MATSUMURA-TUNDISI), ix-x. CRC Press. Boca Ratón (FL).

THOREAU, H. D. 1854. Walden. Ticknor and Fields. Boston. 357 pp.

TILMAN, D., P. B. REICH, J. KNOPS, D. WEDIN, T. MIELKE \& C. LEHMAN. 2001. Diversity and productivity in a long-term grassland experiment. Science, 294: 843-845. DOI: 10.1126/science. 1060391

TUNDISI, J. \& T. MATSUMURA-TUNDISI. 2012. Limnology. CRC Press. Boca Ratón (FL). $888 \mathrm{pp}$.

VERMAAT, J. E., J. A. DUNNE \& A. J. GILBERT. 2009. Major dimensions in food-web structure properties. Ecology, 90: 278-282. DOI: 10.1890/07-0978.1

VILLAR-ARGAIZ, M., J. M. MEDINA-SANCHEZ, B. A. BIDDANDA \& P. CARRILLO. 2018. Predominant non-additive effects of multiple stressors on autotroph $\mathrm{C}: \mathrm{N}: \mathrm{P}$ ratios propagate in freshwater and marine food webs. Frontiers in Microbiology, 9. DOI: 10.3389/fmicb.2018.00069

VOLLENWEIDER, R. A. 1968. Scientific fundamentals of the eutrophication of lakes and flowing waters, with particular reference to nitrogen and phosphorus as factors in eutrophication. OECD Technical Report DAS/CSI/ 68.27. OECD. Paris. 159 pp.

VOLLENWEIDER, R. A. 1975. Input-output 
models, with special reference to the phosphorus loading concept in Limnology. Schweizerische Zeitschrift für Hydrologie, 37: 53-84. WETZEL, R. G. 2001. Limnology. Lake and river ecosystems. 3rd edition. Academic Press and Elsevier. San Diego. 1006 pp.
WOOD, S. N. 1997. Inverse problem and structured-population dynamics. In: Structured-population models in marine, terrestrial and freshwater systems (S. TULJAPULKAR \& H. CASWELL, eds.), 555-586. Chapman \& Hall. New York. 